\title{
Assessment of Physicochemical Properties and Mineral Compositions of Almond (Prunus amygdalus) Gum of Libyan Origin
}

\author{
M.H. Awad ${ }^{1, *}$, Aborawi M. Elgornazi², Nouri M.A. Soleiman ${ }^{1}$ \\ ${ }^{1}$ Departiment of Chemistry, College of Arts and Sciences-Kasr Khiar, Elmergib University, Alkoms - 40414, Libya. \\ ${ }^{2}$ Faculty of Education Tripoli, University of Tripoli, Suq Aljumea - 40405, Libya.
}

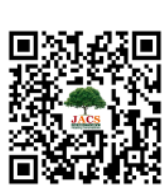

\section{A R T I C L E D E T A I L S}

Article history:

Received 28 December 2020

Accepted 15 January 2021

Available online 07 February 2021

\section{Keywords:}

Prunus amygdalus

Almond Gum

Mineral Composition

\begin{abstract}
A B S T RA C T
Twenty-five authentic samples of Prunus amygdalus gum samples were collected from five different locations in northwest of Libya. Different physicochemical methods were used to characterize this type of gum samples. The mean values of the moisture ranged from 12.55 to $14.93 \%$, ash mean values 4.03 to $4.62 \%$, pH 3.89 to 4.40 , W.H.C 52.85 to $60.0 \%$, and O.H.C 136.2 to $156.3 \%$. Solubility of Prunus amygdalus gum showed that it had low solubility in distilled water with the mean values ranged from 20.01 to $35.40 \%$, but it dissolved perfectly in alkali media where solubility increased to $96.3 \%$ in $0.05 \mathrm{M}$ $\mathrm{Na}_{2} \mathrm{CO}_{3}$. The study exhibited that the mean values of cationic concentration in $\%(\mathrm{w} / \mathrm{w})$ such as calcium was ranged from 0.552 to 0.585 , potassium 0.402 to 0.505 , iron 0.0975 to 0.1125 , and sodium 0.064 to 0.079, which indicates that $\mathrm{Ca}$ has the highest concentration of metallic ions present. Atomic absorption method indicate that all samples contain traces of elements, $\mathrm{Li}, \mathrm{Cr}, \mathrm{Mn}, \mathrm{Ni}, \mathrm{Zn}, \mathrm{Pb}, \mathrm{Hg}$, and $\mathrm{Cd}$. The main functional groups recorded from FTIR spectrum included bands at $3293 \mathrm{~cm}^{-1}$ (O-H in carboxylic group), $1601.77 \mathrm{~cm}^{-1}(\mathrm{C}=\mathrm{O}$, amide $\mathrm{N}-\mathrm{H}$ bend, and $\mathrm{C}=\mathrm{C}), 1357.53 \mathrm{~cm}^{-1}\left(\mathrm{CH}_{3^{-}}\right.$, and $\mathrm{C}-\mathrm{O}-\mathrm{H}$ in- plane bending vibration), and $1025.74 \mathrm{~cm}^{-1}$ (C-O stretching).
\end{abstract}

\section{Introduction}

Almond trees are Mediterranean trees where they grow in Syria, Lebanon, Turkey, Palestine, Jordan, Tunisia, Algeria, Morocco and Libya $[1,2]$. It also grows in other countries such as the United States of America, which is one of the largest producers of almond fruits. Almond Gum, otherwise known in Libya as the almond tear, is an exudate of the Prunus Amygdales tree belonging to the family Rosacea. Furthermore, Prunus Amygdales Batsch is known by such different designations as Prunus dulcis (Miller), Prunus communis L. potoni, and recently designation as Amygdalus communis L. [3-5]. Verbeken et al. reported that, the natural exudate gums are produced as a result of microbial infection on the bark of Acacia trees, and this trees in turn exudate the viscous liquid as a defense mechanism to seal off the injure and block more invasion of the tissue [6], as Acacia gums, almond gum are defined as dried exudates obtained from the trunks and branches of almond trees. Polysaccharide gums obtained from varieties of Acacia species are widely used in food and pharmaceutical industries [6,7]. Recently, due to the extensive applications of almond gum in confectionary and beverage industries for flavor encapsulation. Almond gum was blended with plum, Acacia senegal, ghatti, and tragacanth gum to improving their emulsification properties in food industrial applications [3]. Also the recent studies reveled that, almond gum consist mainly arabinogalactan polysaccharides due to the high composition of arabinose $(52.1 \%)$ and galactose $(33.42 \%)$ sugars, with small proportions of xylose (4.8\%), rhamnose $(0.43 \%)$, glucose $(0.15 \%)$, and mannose $(0.18 \%)$ sugars $[3,8,9]$. Mahfoudhi et al. reported that almond gum consist high amounts of carbohydrates and proteins as well as a low amount of fatty acid were present [9]. Almond gum is also relatively rich in metal composition, especially calcium, potassium, iron, and magnesium $[3,9,10]$. The physicochemical and functional properties of the natural exudates gum are play and important role in determining their commercial value and their use. These properties differ with gums different, botanical source, and even a large differences in gums from the same species when collected from plants that growing under different climatic conditions, or even when collected from the same plant species at different seasons of the year [11]. On the other hand, these properties

*Corresponding Author:muhash.co1@gmail.com (M.H. Awad) may also be affected by the way of gum treatment after collection such as extraction, purification, drying, and storage temperature, also these properties may be affected by the age of the tree, and type of soil [12]. About $95 \%$ of Libya is desert, and almost the cultivated soils in Libya are xerosols and yermosols, and usually are dunes or shifting sandy in texture, with low in organic matter content and water holding capacity [13]. This work aims to physicochemically characterize and evaluate the concentrations of metals in Almond gum of Libyan origin as a preliminary study to pave the way for its industrial and commercialization applications.

\section{Experimental Methods}

\subsection{Origin of the Gum Specimens}

Twenty-five almond gum samples were collected during 2017-2018, from authenticated trunk of Prunus Amygdales trees growing in five location in the northwest region of Libya (Fig. 1), and collected five samples for each locality and labeled (A1, A2, A3, A4, and A5) for easy identification. The samples were hand cleaned to remove any foreign substance. Then few nodules of crude gum were ground finely using a pestle and mortar and stored in clean, labeled plastic bottles until used.

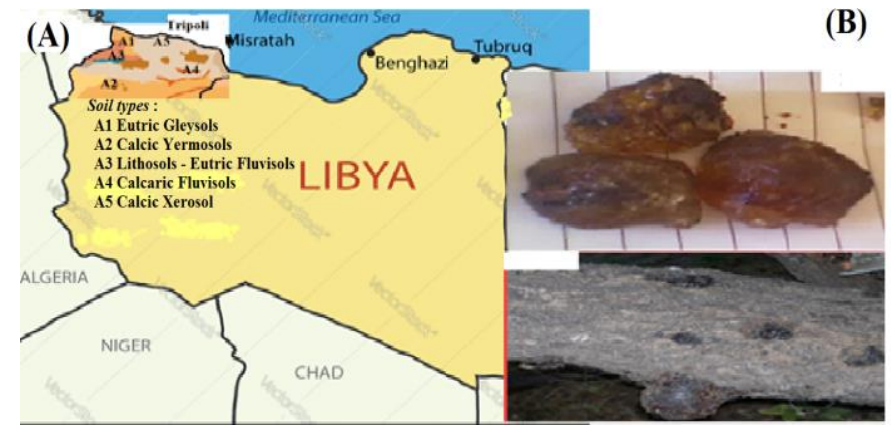

Fig. 1 (A) Soil map of northwest of Libya and (B) Crude Prunus amygdalus natural exudates gum 


\subsection{Physicochemical Analysis}

Solubility was determined by dissolving $1.0 \mathrm{~g}$ of dry sample in $100 \mathrm{~cm}^{3}$ of distilled water and mixed in roller mixer overnight, then the solution centrifuged at $600 \mathrm{rpm}$ for 30 minutes. $10 \mathrm{~cm}^{3}$ of gum superannuated was placed in petri dish and dried at $105{ }^{\circ} \mathrm{C}$ for $1 \mathrm{hr}$, cooled and weighed $[14,15]$. Then the solubility was calculated as the percentage $\%(w / w)$. Moisture content was measured according to FAO paper No. 49 (1990) after incubation of fine powder gum samples at $105^{\circ} \mathrm{C}$ for $24 \mathrm{hr}[16,17]$, Ash percentage was determined by incinerating dry powder samples in a muffle furnace at $550^{\circ} \mathrm{C}$ for $6 \mathrm{hr}$ [17]. The $\mathrm{pH}$ value of gum samples $1.0 \%$ $(\mathrm{w} / \mathrm{w})$ were determined using a glass electrode $\mathrm{pH}$ meter (Jenway- Model 3505) according to AOAC, 1990 method [18].

\subsection{Water- and Oil -Holding Capacity (WHC, OHC)}

$1.0 \mathrm{~g}$ of almond gum was accurately weighed in a clean petri dish, then it was placed in a desiccator half filled with distilled water, and incubated for certain length of time: $24,48,96,120$, and $144 \mathrm{hr}$. The petri dish with sample was then reweighed. The increase in weight gave the W.H.C. of the sample per weight $\%(\mathrm{w} / \mathrm{w})$ and finally expressed as percentage [19].

The oil holding capacity was also measured by dispersing $0.5 \mathrm{~g}$ of almond gum powders in $10 \mathrm{~cm}^{3}$ of refined edible sunflower oil in centrifuge tube. The mixture was stirred for $4 \mathrm{~min}$ followed by centrifuge at $600 \times \mathrm{g}$ for $1 \mathrm{~h}$. Finally, $\mathrm{OHC}$ was determined according to the following equation,

$$
\text { OHC } \%(w / w)=\left(\frac{\text { weight of swollen sample }- \text { weight of dry sample }}{\text { weight of dry sample }}\right) \times 100
$$

\subsection{Intrinsic Viscosity Measurement}

The intrinsic viscosity measurements were performed in a Ubbelohde Capillary Viscometer (Schott Kapillar - Viskosimeter Typ- Nr 530 -20, Germany) equipped in a water bath to maintain the temperature at $25 \pm$ $0.1{ }^{\circ} \mathrm{C}$, then intrinsic viscosity $[\eta]$ was determined according to the following equations [9],

$$
\begin{aligned}
& \frac{\left(\eta_{s p}\right)}{C}=[\eta]+k_{S P}[\eta]^{2} C \\
& \frac{\left(\ln \eta_{i n h}\right)}{C}=[\eta]+k_{i n h}[\eta]^{2} C
\end{aligned}
$$

where $\mathrm{k}_{\text {inh }}$ and $\mathrm{k}_{\mathrm{sp}}$ are constants that depend on the polysaccharides / solvent pair. The [ $\eta]$ was determined as the limit of the inherent viscosity or of the ratio between the specific viscosity and the gum concentration when the gum concentration approaches zero.

$$
[\eta]=\lim _{c \rightarrow 0} \eta_{\text {inh }}=\lim _{\mathrm{c} \rightarrow 0} \eta_{s p}
$$

The intrinsic viscosity of soluble fraction gum was related to the molecular mass according to the Mark- Houwink equation,

$$
[\eta]=\mathrm{K}\left[\mathrm{M}_{\mathrm{v}}\right]^{\alpha}
$$

where the constant parameters $\mathrm{K}$ and $\alpha$ depend on the nature of molecule and solvent, and on the temperature [20].

\subsection{Salt Tolerance (S), and Chain Stiffness Parameter (B)}

The value of salt tolerance (S) was determined from the Smidsrød and Haug equation:

$$
[\eta]_{0}=[\eta]_{0}^{\infty}+S \times 1 / \sqrt{\mu}
$$

where $[\eta]_{0}^{\infty}$ is the intrinsic viscosity at infinite ionic strength $(\mu)$, then the chain stiffness parameter (B) was obtained from the below equation: $S=B \times\left([\eta]_{0}^{0.1}\right)^{v}$, where the exponent $\mathrm{v}$ used for this study equal to 1.3 [15].

\subsection{Mineral Content}

About $2.0 \mathrm{~g}$ of dry gum samples were ignited in muffle furnace at $550{ }^{\circ} \mathrm{C}$ for $6 \mathrm{hr}$. Then the ash was cooled and dissolved in $50 \mathrm{~cm}^{3}$ of $0.5 \mathrm{M}$ Nitric acid. The solution was warmed for 10 minutes to dissolve the ash, then the solution cooled, filtered and diluted to $100 \mathrm{~cm}^{3}$ volume with deionized water and well mixed [17].

The essential elements as potassium, sodium, calcium, barium, and lithium were determined using a flame photometer (BWB Technologies, UK), while the heavy elements concentrations were measured using atomic absorption spectroscopy (Shimadzu AA 6701 F; A. A Spectrophotometer; Shimadzu Ltd, Japan) adapted with hollow cathode lamp.

\subsection{Infra-Red Spectroscopy}

The infra-red spectra of the crude gum sample in potassium bromide was recorded with FTIR spectrometer - Bruker, Model Tensor II, United States.

\section{Results and Discussion}

Spherically and irregular - shaped nodules of almond gum are deep brown color (Fig. 1). However, nodules when crushed and ground they give a clear white powder. Table 1 shows the results of physicochemical properties of almond gum samples.

The mean values of moisture content of the crude gum samples ranged from 12.55 to $14.93 \%$, however, the mean values range reported here was slightly higher than the mean value of $10.3 \%$ indicated by Imtiyaz and Najeeb for Prunes amygdalus var Dulcis gum collected from Kashmir valley [21]. Results obtained were within the mean value $14.89 \%$ reported by Bouaziz et al. for almond gum collected from trunks of Achaak's variety trees in the suburb of Sfax City -Tunisia [10].

In the present investigation, the mean values range of solubility for natural almond gum samples were ranged from 20.01 to $35.40 \%$ in distilled water with a gel fraction ranged from 79.9 to $64.6 \%$. Solubility of gum increased with removal calcium ions and H-bonds of the gum solution, in 0.05 M EDTA the solubility mean values were ranged from 37.2 to $45.6 \%$ and extended to $96.9 \%$ in 0.05 sodium carbonate at $\mathrm{pH}$ above 10 The behavior of almond gum solubility differs of ghatti gum, and similar to Combretum glutinosum gum [15].

The ash percentage indicates the presence of inorganic metals in gum samples, also ash content is a good parameter describe the purity, substitution, and adulteration of gums. Anderson and Dea reported that the type of the soil affects the ash content significantly, and usually heavy soil gave ash content higher than the sand soil [22], but this study showed that the location had no effect on the ash content of the Almond gum samples (insignificant differences). Table 1 shows that the mean values of

\begin{tabular}{|c|c|c|c|c|c|c|c|c|c|}
\hline \multirow{2}{*}{ Location } & \multirow{2}{*}{ Moisture\% } & \multicolumn{3}{|c|}{ Solubility $(\% \mathrm{~W} / \mathrm{W})$} & \multirow{2}{*}{-Ash content $\%$} & \multirow[b]{2}{*}{$\mathrm{pH}$} & \multirow{2}{*}{ WHC\% } & \multirow{2}{*}{$\mathrm{OHC} \%$} & \multirow{2}{*}{ Tannins } \\
\hline & & D.W. & $0.05 \mathrm{M}$ EDTA & $0.05 \mathrm{M} \mathrm{Na}_{2} \mathrm{CO}_{3}$ & & & & & \\
\hline$\overline{\mathrm{A} 1}$ & $12.55 \pm 0.95$ & $20.1 \pm 7.11$ & $37.6 \pm 2.21$ & $95.3 \pm 3.87$ & $4.62 \pm 0.23$ & $4.32 \pm 0.13$ & $52.85 \pm 6.72$ & $136.2 \pm 8.72$ & - \\
\hline $\mathrm{A}_{2}$ & $14.38 \pm 0.35$ & $29.0 \pm 7.23$ & $37.2 \pm 2.03$ & $95.7 \pm 3.66$ & $4.22 \pm 0.28$ & $4.14 \pm 0.17$ & $55.56 \pm 6.56$ & $142.0 \pm 6.51$ & - \\
\hline $\mathrm{A}_{3}$ & $13.52 \pm 0.68$ & $35.4 \pm 8.32$ & $45.6 \pm 3.32$ & $96.2 \pm 2.96$ & $4.43 \pm 0.13$ & $4.40 \pm 0.16$ & $56.00 \pm 6.63$ & $137.6 \pm 8.37$ & - \\
\hline $\mathrm{A}_{4}$ & $12.63 \pm 0.85$ & $31.6 \pm 7.43$ & $43.1 \pm 2.73$ & $95.6 \pm 3.37$ & $4.19 \pm 0.22$ & $3.98 \pm 0.22$ & $57.14 \pm 6.33$ & $145.0 \pm 9.94$ & - \\
\hline$A_{5}$ & $14.93 \pm 0.98$ & $29.6 \pm 6.91$ & $43.7 \pm 3.02$ & $96.9 \pm 2.24$ & $4.03 \pm 0.16$ & $3.89 \pm 0.23$ & $60.00 \pm 6.79$ & $156.3 \pm 5.68$ & - \\
\hline
\end{tabular}
the ash percentage were ranged from 4.03 to $4.62 \%$, which are slightly higher than value 3.86 reported by Bashir and Haripriya for Prunus dulcis gum [23], which is less than the value $6.66 \%$ recommended by Imtiyaz

\begin{tabular}{|c|c|c|c|c|c|c|c|c|c|c|c|c|}
\hline Location & $\mathrm{Ca} \%$ & $\mathrm{~K} \%$ & $\mathrm{Fe} \%$ & $\mathrm{Na} \%$ & $\mathrm{Li} \%$ & $\mathrm{Ni} \%$ & $\mathrm{Cr} \%$ & Mn\% & $\mathrm{Zn} \%$ & $\mathrm{~Pb} \%$ & $\mathrm{Hg} \% \times 10^{-7}$ & $\mathrm{Cd} \% \times 10^{-4}$ \\
\hline $\mathrm{A} 1$ & 0.552 & 0.420 & 0.1125 & 0.075 & 0.003 & 0.00025 & 0.0035 & 0.0075 & 0.00225 & 0.00228 & 4.77 & 2.50 \\
\hline A2 & 0.554 & 0.430 & 0.1050 & 0.070 & 0.005 & 0.00025 & 0.0083 & 0.0080 & 0.0025 & 0.00225 & 5.31 & 2.52 \\
\hline A3 & 0.585 & 0.467 & 0.0975 & 0.067 & 0.003 & 0.00025 & 0.0019 & 0.0065 & 0.00025 & 0.00225 & 2.75 & 2.55 \\
\hline A4 & 0.567 & 0.505 & 0.1075 & 0.079 & 0.004 & 0.00025 & 0.0083 & 0.0076 & 0.00275 & 0.0075 & 4.00 & 2.53 \\
\hline A5 & 0.575 & 0.402 & 0.1200 & 0.064 & 0.004 & 0.00025 & 0.0035 & 0.0091 & 0.002278 & 0.0025 & 4.03 & 2.50 \\
\hline
\end{tabular}
and Najeeb [21].

Table 1 Analytical data of physicochemical characterization of almond gum

All values are expressed as: mean \pm standard deviation ; - = absent

Table 2 Mineral composition of almond gum

All values are expressed as mean

https://doi.org/10.30799/jacs.232.21070102 
It also seen in Table 1 that the $\mathrm{pH}$ of almond gum solution was found to be acidic due to the presence of few free carboxyl group of its constituent acidic residues such as D-glucouronic acid. The mean values of $\mathrm{pH}$ of almond gum solution were ranged from 3.89 to 4.40 , which are slightly lower than value of 4.87 given by Rezaei et al. [3], and value 5.82 reported by Imtiyaz and Najeeb [21].

The ability of almond gum to hold water against gravity was recorded as water holding capacity, and studies have shown that the mean values of WHC of gum samples had been found to range between 52.85 to $60.0 \%$. This range disagrees with the value (91\%) obtained by Grasso et al., [24]. As shown in Table 1, the mean value of $\mathrm{OHC}$ of gum samples ranged from 136.6 to $156.3 \%(\mathrm{w} / \mathrm{w})$, which are higher than value $90.0 \%(\mathrm{w} / \mathrm{w})$ reported by Bashir and Haripriya of Prunus dulcis gum in mustard oil [23], and lower than the value $163 \%(\mathrm{w} / \mathrm{w})$ reported by Bouaziz et al. for Almond (Achaak's variety) gum collected from suburb of Sfax city (Tunisia) [14]

The above results show that the location has no significant effect on the physicochemical properties of natural Prunus amygdalus gum, these may be due to the similarity between the all locations in climate condition, rainfall, and other ecological factors. These results also support the findings of Siddig [25] who reported that the soil type (and time of picking), rainfall and temperature had no significant effect in Acacia senegal gum physicochemical properties. Ballal et al. found that yield of Acacia senegal gum was affected by the temperature, rainfall, and time of tapping [26].

Fig. 2 shows that the intrinsic viscosity $\left(\mathrm{cm}^{3} / \mathrm{g}\right)$ of water-soluble fraction of almond gum in $1.0 \mathrm{M}$ sodium chloride was found to be 20.05 $\mathrm{cm}^{3} / \mathrm{g}$, and the values of Huggins constant $\left(\mathrm{K}_{\mathrm{sp}}\right)$, and Kraemer constant $\left(\mathrm{K}_{\text {inh }}\right)$ equal 3.63 , and $-1.51 \mathrm{dL} / \mathrm{g}$, respectively of water-soluble fraction of almond gum. The viscosity average molar mass (Mv) dependence of [ $\eta]$ for soluble fraction gum could be represented by The Mark-Houwink equation bellow,

$$
20.04=1.31 \times 10^{-3}\left[\mathrm{M}_{\mathrm{v}}\right]^{0.58}(\mathrm{~g} / \mathrm{mol})
$$

The $M_{v}$ of water soluble fraction of almond gum equal $16.42 \times 10^{6}$ $\mathrm{g} / \mathrm{mol}$. This result slightly higher than the value $15.9 \times 10^{6} \mathrm{~g} / \mathrm{mol}$ of weight average molecular weight (Mw) of water soluble fraction of almond gum reported by Rezaei et al. [3].

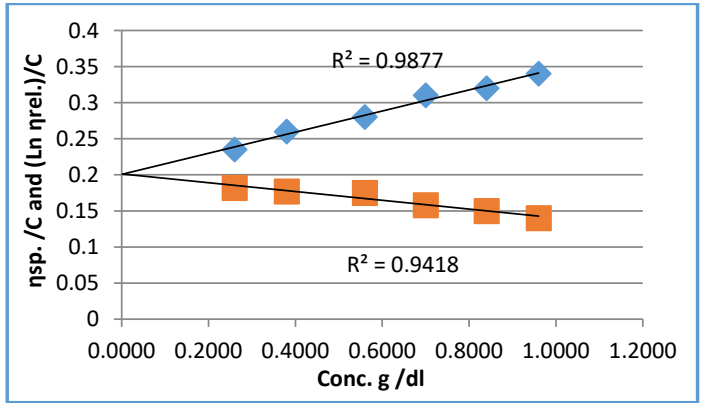

Fig. 2 Combined Huggins $(\downarrow)$ and Kraemer, ( $\bullet$ ) Extrapolation to zero concentration for soluble fraction of almond gum

Fig. 3 shows that the values of constant salt tolerance $(S)$, and the intrinsic viscosity at infinite ionic strength $\left(\eta_{0}^{\infty}\right)$ were found to be $0.054 \mathrm{dL}$ $\times \mathrm{M}^{1 / 2} / \mathrm{g}$, and $0.143 \mathrm{dL} / \mathrm{g}$ respectively, the constant (S) is strongly dependent on polymer molecular mass (Mw) and the nature of counter ions. The constant (S) value of several polymer backbone can be developed only when the comparison was expressed at a specific Mw. According to this fact, Smidsrod and Haug introduced a new parameter (B) as an empirical chain stiffness which is independent on the polymer Mw. The value of B for the water-soluble fraction of gum Almond gum was found to be 0.649 by using the $u$ constant equal to 1.3 .

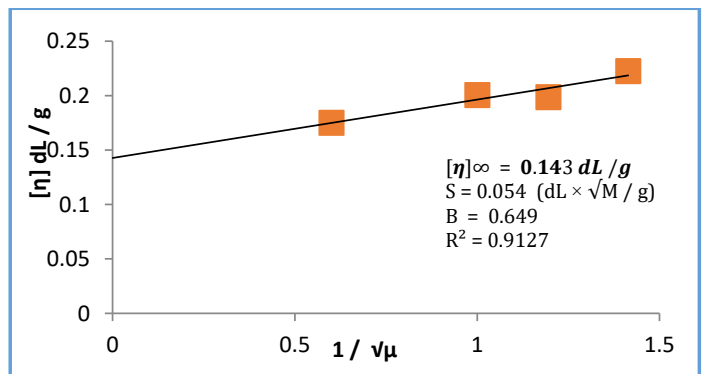

Fig. 3 [ $\eta$ vs. inverse square root of ionic strength plot for water soluble fraction of almond gum with sodium chloride

https://doi.org/10.30799/jacs.232.21070102

\subsection{Mineral Composition}

Mineral composition is a measure of the amount of specific inorganic elements present within a gum samples. Table 2 shows that the $\mathrm{Ca}, \mathrm{K}$, and $\mathrm{Fe}$ are the three most abundant elements, and other of lower concentration are present in almond gum samples. Fig. 4 shows that the $\mathrm{Ca}, \mathrm{K}, \mathrm{Fe}$, and $\mathrm{Na}$ are found in the same amount in all almond gum samples in spite of the typically differences between the five locations in soil nature. The mean values of calcium content ranged from 0.552 to $0.585 \%$ $(\mathrm{w} / \mathrm{w})$. These range values are higher than that reported by Mahfoudhi et al. $(0.1425 \%$ ) [9], and lower than that observed by Bouaziz et al. $(0.98 \%)$ [10]. The values of potassium content ranged from 0.402 to 0.505 $\%(\mathrm{w} / \mathrm{w})$, these values lower than that presented by Mahfoudhi et al. $(1.1123 \%)$, and this indicates that almond gum is a good source of Ca and $\mathrm{K}$ ions. The sequence of arrangement is $\mathrm{Ca}>\mathrm{K}>\mathrm{Na}$. Similar observation has been reported previously by Rezaei et al. [3]. This sequence is different from $(\mathrm{K}>\mathrm{Ca}>\mathrm{Na}$ ) that reported by Mahfoudhi et al. [9]. Table 2 shows that the mean values of $\mathrm{Li}, \mathrm{Ni}, \mathrm{Cr}, \mathrm{Mn}, \mathrm{Zn}$ elements were found as traces value in almond gum samples, and all the values falls within the range of the limits specified for heavy elements in food grade gums additives. $\mathrm{Pb}$, $\mathrm{Hg}$, and $\mathrm{Cd}$ are high toxic elements at certain concentration. However, concentrations of $\mathrm{Cd}, \mathrm{Hg}$, and $\mathrm{Pb}$ obtained in this study are below the standard limit in British Pharmacopoeia [27]. As mentioned above, Table 2 shows that the effect of location on values of $\mathrm{Li}, \mathrm{Ni}, \mathrm{Cr}, \mathrm{Mn}, \mathrm{Zn}, \mathrm{Pb}, \mathrm{Hg}$, and Cd was not significant, and there is no significant differences among the values of elements in almond gum samples due to the locations.

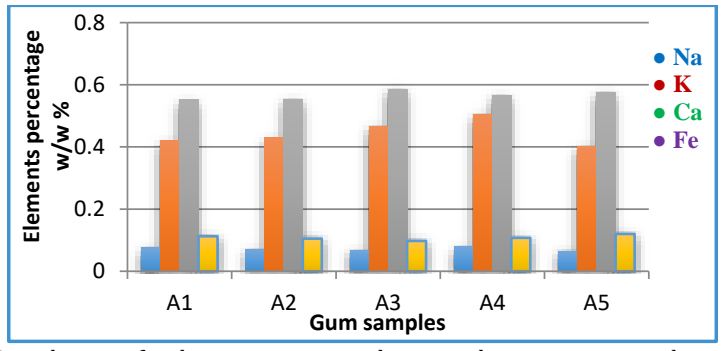

Fig. 4 Distribution of sodium, potassium, calcium, and iron in gum samples

\subsection{Infrared Spectroscopy}

Fig. 5 shows the IR spectra of almond gum depict a characteristic absorption broad peak in $3293 \mathrm{~cm}^{-1}$ representing the presence of hydrogen bonded 0-H group. The bands at 2926 and $2899 \mathrm{~cm}^{-1}$ represent the presence of polysaccharides, and these values related to $\mathrm{C}-\mathrm{H}$ Asymmetry and symmetry stretch vibration bond respectively. The other intense FTIR band at $1601.77 \mathrm{~cm}^{-1}$ represent the presence of $\mathrm{C}=\mathrm{C}$ stretch, and amide $\mathrm{N}-\mathrm{H}$ bend from aliphatic and aromatic galactoproteins, and $\mathrm{COOH}$ (carboxylic group) from amino acids. Carboxylic acids of glucuronic acid residues of gum polysaccharides show characteristic, $\mathrm{C}=0$ symmetric stretching, and $\mathrm{O}-\mathrm{H}$ in-plane bands at 1601.77 and 1414.28 , respectively $[28,29]$. Peaks at $1553.58,1530.29,1512.86$, and 1500.27 represent of C$\mathrm{N}-\mathrm{H}$ bent of trans amide II. The band at $1357.53 \mathrm{~cm}^{-1}$ represent both $\mathrm{C}-\mathrm{O}-$ $\mathrm{H}$ in- plane bending vibrations and deformations, and methyl ester $\mathrm{CH}_{3}$ bending vibrational, which could come, for instance, from 4-0Meglucuronic acids and proteins in polysaccharides backbone [30]. A high intensity band at $1025.74 \mathrm{~cm}^{-1}$ represents $\mathrm{C}-\mathrm{O}$ stretching vibration. The peak at $893.74 \mathrm{~cm}^{-1}$ represent alkene $\mathrm{C}-\mathrm{H}$ bend from polysaccharides backbone, also indicates the $\beta$-glycosidic linkages mainly present in galactose and mannose units in polysaccharides backbone [31], also the peak at $893.74 \mathrm{~cm}^{-1}$ represent of $-\mathrm{NH}_{2}$ at about $836.17 \mathrm{~cm}^{-1}$. Peaks observed at $668.38 \mathrm{~cm}^{-1}$ represent $0-\mathrm{H}$ out of plane bending band. Additionally, bands at 648.91 and $606.57 \mathrm{~cm}^{-1}$, which are attributed to combination of $\mathrm{CO}$ vibrational of arabinose ring and various rings deformation modes. The bands at 575.15, 562.64, 553.28, 537.96, and $527.93 \mathrm{~cm}^{-1}$ represent the presence of $\beta(\mathrm{C}-\mathrm{C}-\mathrm{C}), \beta(\mathrm{C}-\mathrm{O}-\mathrm{C})$ in glycosidic linkage [32].

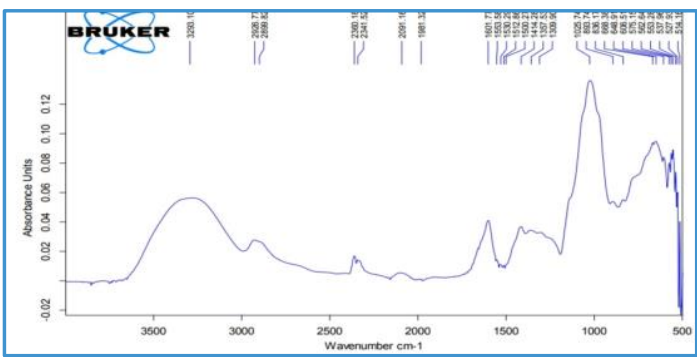

Fig. 5 FTIR Spectrum of almond gum 


\section{Conclusion}

The obtained results indicate that Prunus amygdalus gum is considered as acidic polysaccharide with low solubility in cold distilled water. Location has no significant effect on physicochemical properties and mineral composition of almond gum. The data analysis of this study clearly showed that almond gum have good physicochemical properties and good concentration of essential elements, which agree with the values reported by the FAO/WHO (JECFA) specification for Gum Arabic. Thus, Prunus amygdalus gum can be utilized in gum-based industries, most importantly in pharmaceuticals and food as emulsifier in food processing and effective binder in drug formulations.

\section{Acknowledgements}

The first author would like to thank Department of Chemistry, Faculty of Art and Science Kasr Khiar, El-Mergib University- Libya, for their greatly appreciate support this study.

\section{References}

[1] F. Bouaziz, M.B. Romdhane, C.B. Helbert, L. Buon, F. Bhiri, et al., Healing efficiency of oligosaccharides generated from almond gum (Prunus amygdalus) on dermal wounds of adult rats, J. Tissue Viability 23 (2014) 98-108.

[2] G. Ladizinsky, On the origin of almond, Genet. Resour. Crop Evolut. 46 (1999) 143-147

[3] A. Rezaei, A. Nasirpour, H. Tavanai, Fractionation and some physicochemical properties of almond gum (Amygdalus communis L.) exudates, Food Hydrocolloid. 60 (2016) 461-469.

[4] S. Yada, K. Lapsley, G. Huang, A review of composition studies of cultivated almonds: macronutrients and micronutrients, J. Food Compost. Anal. 24 (2011) 469-480.

[5] S. Yada, G. Huang, K. Lapsley, Natural variability in the nutrient composition of California grown almonds, J. Food Compost. Anal. 30 (2013) 80-85.

[6] D. Verbeken, S. Dierckx, K. Dewettinck, Exudate gums: occurrence, production, and applications, Appl. Microbiol. Biotechnol. 63 (2003) 10-21.

[7] G.R, Sanderson, Gums and their use in food systems, Food Technol. 50 (1996) 81-84.

[8] J.A. Rastabi, A. Nasirpour, Comparison of some physicochemical and functional properties of farsi gum and other rosaceae plant gum exudates, J. Sci. Eng. Elites 1 (2017) 110-118.

[9] N. Mahfoudhi, M. Chouaibi, F. Donsı, G. Ferrari, S. Hamdi, Chemical composition and functional properties of gum exudates from the trunk of the almond tree (Prunus dulcis), Food Sci. Technol. Int. 18(3) (2012) 241-250.

[10] F. Bouaziz, C.B. Helbert, M.B. Romdhane, M. Koubaa, F. Bhiri, et al., Structural data and biological properties of almond gumoligosaccharide: Application to beef meat preservation, Int. J. Biol. Macromol. 72 (2015) 472-479.

[11] J.K. Lelon, I.O. Jumba, J.K. Keter, W. Chemuku, F.D.O. Oduor, Assessment of physical properties of gum Arabic from Acacia senegal varieties in Baringo District, Kenya. Afr. J. Plant Sci. 4(4) (2010) 95-98.
[12] A.B. Asma, K.S. Murwan, E.A. Abu, Effect of tree and nodule age on some physicochemical properties of gum from Acacia senegal (L.) Wild., Sudan, Res. J. Agri. Biol. Sci. 3(6) (2007) 866-870.

[13] H.A. Zurqani, E.A. Mikhailova, C.J. Post, M.A. Schlautman, A.R. Elhawej, A review of Libyan soil databases for use within an ecosystem services framework, Land 8(82) (2019) 2-30.

[14] F. Bouaziz, M. Koubaa, K.B. Jeddou, F.J. Barba, F. Chaari, et al., Effects of almond gum as texture and sensory quality improver in wheat bread, Int. J. Food Sci. Technol. 1 (2016) 1-9.

[15] M.H. Awad, Solution properties of Combretum glutinosum (Habeil) Gum, Int. J. Chem. 7(2) (2015) 49-56.

[16] FAO, Food and nutrition paper, No.49, Rome, 1990

[17] D. Yebeyen, M. Lemenih, S. Feleke, Characteristics and quality of gum Arabic from naturally grown Acacia senegal (Linne) Willd. trees in the central rift valley of Ethiopia, Food Hydrocoll. 23 (2009) 175-180.

[18] AOAC, Association of official analytical chemists, official methods of analysis $15^{\text {th }}$ Ed., Washington DC, 1990.

[19] W. Horwitz, Official methods of analysis of the association of official analytical chemists, $13^{\text {th }}$ Edn., Benjamin Franklin Station, Washington D. C., 1980.

[20] L.S. Lai, H.F. Chiang, Rheology of decolorized Hsian-Tsao leaf gum in the dilute domain, Food hydrocolloid. 16 (2002) 427-440.

[21] A.M. Imtiyaz, J. Najeeb, Standardization and characterization of almond gum obtained from Prunus Amygdales var Dulcis, World J. Pharm. Pharm. Sci. 6(8) (2017) 1431-1443.

[22] D.M.W. Anderson, I.C.M. Dea, K.A. Karamalla, J.F. Smith, Studies on uronic acid materials: An analytical study of different forms of the gum from Acacia senegal (Willd), Carbhyd. Res. 6 (1968) 97-103.

[23] M. Bashir, S. Haripriya, Assessment of physical and structural characteristics of almond gum, Int. J. Biol. Macromol. 93 (2016) 476-482.

[24] N. Grasso, L.A. Miravalles, J.A.O. Mahony, Composition, physicochemical and sensorial properties of commercial plant-based yogurt, Foods 9(252) (2020) $2-11$.

[25] N.E. Siddig, Nitrogen and specific rotation as qualifying indices for gum Arabic derived from Acacia senegal (L) willd, MSc. Thesis, University of Khartoum, Sudan, 1996.

[26] M.E. Ballal, E.A. El Siddig, M.A. Elfadl, O. Luukkanen, Relationship between environmental factors, tapping dates, tapping intensity and gum Arabic yield of an Acacia senegal plantation in western Sudan, J. Arid Environ. 63 (2005) 379-389.

[27] British Pharmacopoeia, Medicine commission, (I and II), Stationery office, London, UK, 1980

[28] J.C. Boulet, P. Williams, T. Doco, A Fourier transform infrared spectroscopy study of wine polysaccharides, Carbohyd. Polym. 69(1) (2007) 79-85.

[29] G.D. Manrique, F.M. Lajolo, FT-IR spectroscopy as a tool for measuring degree of methyl esterification in pectins isolated from ripening papaya fruit, Postharvest Biol. Technol. 25(1) (2002) 99-107.

[30] A. Barth, Infrared spectroscopy of proteins, Biochim. Biophys. Acta 1767(9) (2007) 1073 -1101.

[31] M. Kacurakov, P. Capek, V. Sasinkov, N. Wellner, A. Ebringerov, FT-IR study of plant cell wall model compounds: pectic polysaccharides and hemicelluloses, Carbohyd. Polym. 43 (2000) 195-203.

[32] E. Wiercigroch, E. Szafraniec, K. Czamara, M.Z. Pacia, K. Majzner, et al., Raman and infrared spectroscopy of carbohydrates: A review, Spectrochim. Acta A: 185 (2017) 317-335 